\title{
Distinct phenotypes and 'bystander' effects of senescent tumour cells induced by docetaxel or immunomodulatory cytokines
}

\author{
OLENA SAPEGA ${ }^{1,2}$, ROMANA MIKYŠKOVÁ ${ }^{1,2}$, JANA BIEBLOVÁ ${ }^{3}$, BLANKA MRÁZKOVÁ ${ }^{4}$, \\ ZDENĚK HODNÝ ${ }^{4}$ and MILAN REINIŠ ${ }^{1,2}$ \\ ${ }^{1}$ Laboratory of Immunological and Tumour Models; ${ }^{2}$ Department of Transgenic Models of Diseases; \\ ${ }^{3}$ Czech Centre for Phenogenomics and ${ }^{4}$ Laboratory of Genome Integrity, Institute of Molecular \\ Genetics of the Czech Academy of Sciences, v.v.i., Prague 4142 20, Czech Republic
}

Received December 12, 2017; Accepted June 14, 2018

DOI: $10.3892 /$ ijo.2018.4553

\begin{abstract}
Cellular senescence is the process of the permanent proliferative arrest of cells in response to various inducers. It is accompanied by typical morphological changes, in addition to the secretion of bioactive molecules, including proinflammatory cytokines and chemokines [known as the senescence-associated secretory phenotype (SASP)]. Thus, senescent cells may affect their local environment and induce a so-called 'bystander' senescence through the state of SASP. The phenotypes of senescent cells are determined by the type of agent inducing cellular stress and the cell lineages. To characterise the phenotypes of senescent cancer cells, two murine cell lines were employed in the present study: TC-1 and B16F10 (B16) cells. Two distinct senescence inductors were used: Chemotherapeutic agent docetaxel (DTX) and a combination of immunomodulatory cytokines, including interferon $\gamma(\mathrm{IFN} \gamma)$ and tumour necrosis factor $\alpha$ (TNF $\alpha)$. It was demonstrated that DTX induced senescence in TC-1 and B16 tumour cell lines, which was demonstrated by growth arrest, positive $\beta$-galactosidase staining, increased $\mathrm{p} 21^{\text {Waf } 1}$ (p21) expression and the typical SASP capable of inducing a 'bystander' senescence. By contrast, treatment with a combination of T helper cell 1 cytokines, IFN $\gamma$ and $\mathrm{TNF} \alpha$, induced proliferation arrest only in B16 cells. Despite the presence of certain characteristic features resembling senescent cells (proliferation arrest, morphological changes and increased p21 expression), these cells were able to form tumours in vivo and started to proliferate upon cytokine withdrawal. In addition, B16 cells were not able to induce a 'bystander' senescence. In summary, the present study described cell line- and treatmentassociated differences in the phenotypes of senescent cells
\end{abstract}

Correspondence to: Dr Milan Reiniš, Laboratory of Immunological and Tumour Models, Institute of Molecular Genetics of the Czech Academy of Sciences, v.v.i., Vídeňská 1083, Prague 4142 20, Czech Republic

E-mail: milan.reinis@img.cas.cz

Key words: cellular senescence, 'bystander' senescence, docetaxel, immunostimulatory cytokines, tumour microenvironment that may be relevant in optimization of cancer chemo- and immunotherapy.

\section{Introduction}

Cellular senescence is usually defined as a cellular state characterized by specific metabolic, epigenetic, genetic and phenotypical changes culminating in the inability of cells to proliferate (1). These changes rely on substantial modifications of their secretome, transcriptome and proteome $(2,3)$. Typical characteristics of cellular senescence include a flat and large morphology, the presence of vacuoles, positive staining for the senescence-associated $\beta$-galactosidase marker, and the increased expression of specific cyclin-dependent kinase inhibitors, including $\mathrm{p} 16^{\text {Ink4a }}, \mathrm{p} 21^{\text {Waf1 }}$ (p21) and p27 $7^{\mathrm{Kip} 1}$ (4). Senescent cells are often multinucleated, and their nuclei are often larger compared with those in proliferating cells (5). Furthermore, senescent cells exhibit changes in the chromatin structure with the appearance of senescence-associated heterochromatin foci (6).

To date, four different types of senescence have been distinguished: Stress-induced premature senescence (SIPS), replicative senescence (RS), oncogene-induced senescence and oncogene-invalidation-induced senescence (7). The different types of stimuli inducing senescence engage common and specific effector pathways and result in senescent phenotypes that, consequently, share general and specific markers (8). Replicative senescence was first described in 1961 by Hayflick and Moorhead (9) as limited proliferating potential observed in primary human fibroblasts. This type of senescence may be induced by diverse stimuli, including damage to telomeric DNA, resulting in the activation of the DNA damage response $(10,11)$. Compared with RS, SIPS operate independently of telomere attrition and is induced by oxidative stress in addition to by numerous pharmacological drugs (e.g. doxorubicin), bacterial toxins (12), immunomodulatory cytokines [including interferon $\gamma(\mathrm{IFN} \gamma)$ and tumour necrosis factor $\alpha(\mathrm{TNF} \alpha)$ ] or small synthetic and natural compounds (13-15).

Senescent cells secrete a specific pattern of cytokines, chemokines, growth factors and proteases $(16,17)$ that constitute the senescence-associated secretory phenotype (SASP). 
The typical SASP components are immunomodulatory and inflammatory cytokines, including interleukin (IL)-6, IL-8, IL-1, chemokines [e.g. growth-regulated oncogene $\alpha(\mathrm{GRO} \alpha)$ ] and growth factors (e.g. insulin-like growth factor) $(8,18,19)$. It has been demonstrated that SASP is able to reinforce the senescence programme and influence the tissue and tumour microenvironment, affecting tumour and immune cells $(1,20)$. Senescent cells may induce senescence in cells in their surrounding environment via paracrine effects, an effect known as 'bystander' senescence $(17,21,22)$. It is also known that senescence-associated cytokines trigger and maintain the senescence phenotype in an autocrine manner $(23,24)$. Cytokines that are produced by senescent cells may also mediate the impact of ionizing radiation on senescence; in vivo experiments indicated the presence of DNA damage in tissues distant from the irradiated field resembling the radiationlinked 'bystander effect' $(25,26)$.

In the present study, comparative analysis was performed by evaluating the effects of two distinct senescence inductors: Docetaxel (DTX) and a combination of immunomodulatory cytokines, IFN $\gamma$ and TNF $\alpha$ (27). It was previously demonstrated that DTX is able to induce senescence in TC-1 and TRAMP-C2 tumour cell lines (28). However, the tumour growth of proliferating murine TC-1 cancer cells in syngeneic B6 was accelerated by the co-administration of TC-1 or TRAMP-C2 prostate cancer cells made senescent by treatment with DTX, or by lethally-irradiated cells. IFN $\gamma$ and TNF $\alpha$ have been described as potential senescence inducers in vivo in certain tumour cell lines (27). However, further phenotyping and mechanistic studies of DTX and for IFN $\gamma$ and TNFa combined treatment are required in order to understand how tumour cell senescence may serve a function in cancer control and development.

The aim of the present study was to compare the cell phenotypes resulting from two different methods of senescence induction, DTX and IFN $\gamma+\mathrm{TNF} \alpha$, in two distinct murine tumour cell lines, TC-1 and B16. Furthermore, the present study evaluated the ability of culture medium to induce SASP-associated 'bystander' senescence.

\section{Materials and methods}

Cell culture and mice. The TC-1 cell line is generated by the in vitro co-transfection of murine lung C57BL/6 cells with human papillomavirus type 16 (HPV16) E6/E7 and activated human Ha-Ras oncogenes (29). The B16F10 (B16) murine melanoma cell line is syngeneic in $\mathrm{C} 57 \mathrm{BL} / 6$ mice (30). The two cell lines were obtained for the present study from American Type Culture Collection (Manassas, VA, USA). The two cell types were cultured in RPMI-1640 medium (Sigma-Aldrich, Merck KGaA, Darmstadt, Germany) supplemented with $10 \%$ foetal bovine serum (FBS; Gibco; Thermo Fisher Scientific, Inc., Waltham, MA, USA), and antibiotics (gentamicin and nystatin) in standard conditions $\left(5 \% \mathrm{CO}_{2}, 37^{\circ} \mathrm{C}\right.$ and $95 \%$ relative humidity). C57Bl/6NCrl (B6) male mice (weight $\sim 25 \mathrm{~g}$; 7-8 weeks old), were obtained from AnLab, s.r.o. (Prague, Czech Republic) and maintained in specific pathogen-free conditions. The total number of the mice used in the study was 112 . The mice were housed and assayed under a controlled temperature of $22 \pm 2^{\circ} \mathrm{C}$, humidity of $55 \pm 5 \%$ and a 12:12-h light:dark cycle with ad libitum access to rodent chow (Altromin-1310 breeding diet for rats and mice; Altromin Spezialfutter $\mathrm{GmbH}$ \& Co. KG, Lage, Germany) and water (autoclaved, UV disinfected). All experiments were performed according to the EU Directive 2010/63/EU on the protection of animals used for scientific purposes (http://ec.europa.eu/environment/chemicals/lab_animals/legislation_en.htm). Experimental protocols were ethically approved by the Institutional Animal Care Committee of the Institute of Molecular Genetics (Prague, Czech Republic).

Induction of 'primary' premature senescence. TC-1 and B16 cells were cultured in fresh RPMI-1640 medium for $24 \mathrm{~h}$, following which the medium was removed and replaced with medium containing either recombinant IFN $\gamma$ (50 U/ml; R\&D Systems, Inc., Minneapolis, MN, USA) and TNFa (5 ng/ml; PeproTech, Inc., Rocky Hill, NJ, USA) or $7.5 \mu \mathrm{M}$ DTX (Actavis Generics, Dublin, Ireland). The doses of DTX and IFN $\gamma+$ TNF $\alpha$ were optimized to induce senescence but not apoptosis, as reported previously $(17,28)$. To induce senescence, TC-1 and B16 tumour cells were cultured in the medium containing DTX or IFN $\gamma+\mathrm{TNF} \alpha$ for 4 days at $37^{\circ} \mathrm{C}$. IFN $\gamma$ and $\mathrm{TNF} \alpha$ were added to the culture medium each day of the treatment. In this experiment B16 tumour cells were washed following the 4-day treatments and then cultured in fresh medium until day 7 of cultivation. The cell number was counted on days 4 and 7 using an automated cell counter (Countess ${ }^{\circledR}$; Invitrogen; Thermo Fisher Scientific, Inc.).

Induction of 'bystander' senescence. Medium conditioned by medium from senescent or 'parental' tumour cells (control) was used to provoke bystander senescence. First, primary senescence was induced by the cultivation of tumour cells in the RPMI-1640 medium containing either DTX or recombinant IFN $\gamma$ and TNF $\alpha$ for 4 days at $37^{\circ} \mathrm{C}$. The medium was then replaced with fresh medium and cells were cultivated for another $24 \mathrm{~h}$ to prepare senescence-conditioned medium [defined as DTX senescent medium (SM) or IFN $\gamma+\mathrm{TNF} \alpha$ medium (IFN $\gamma+\mathrm{TNF} \alpha \mathrm{M})]$. The medium was then used for the induction of 'bystander' senescence. Tumour cells were cultured for 4 days in fresh medium at $37^{\circ} \mathrm{C}$ mixed with the senescent medium at a ratio of 1:1. As a control, conditioned medium from untreated 'parental' tumour cells was used [defined as tumour medium (TM)].

Senescence-associated (SA)- $\beta$-galactosidase staining. Senescent cells were visualised by estimation of senescence-associated $\beta$-galactosidase activity using the Senescence $\beta$-galactosidase Staining kit (Cell Signaling Technology, Inc., Danvers, MA, USA) according to the manufacturer's protocol. Cell culture images were obtained using an inverted fluorescence microscope Leica DMI6000 with total internal reflection fluorescence illumination at a magnification of x20 (Leica Microsystems GmbH, Wetzlar, Germany).

Reverse transcription-quantitative polymerase chain reaction $(R T-q P C R)$. RNA samples from TC-1 and B16 cell lines were isolated using RNeasy Plus mini kit (Qiagen Sciences, Inc., Gaithersberg, MD, USA) according to the manufacturer's protocol. cDNA was synthesized with random hexamer 
primers using the High-Capacity cDNA Reverse Transcription kit (Applied Biosystems; Thermo Fisher Scientific, Inc.). The temperature profile for RT was $42^{\circ} \mathrm{C}$ for $30 \mathrm{~min}, 99^{\circ} \mathrm{C}$ for $5 \mathrm{~min}$ and $10^{\circ} \mathrm{C}$ for $5 \mathrm{~min}$. RT-qPCR was performed in an LC480II system (Roche Applied Science, Penzberg, Germany) using SYBR Select Master mix containing SYBR Green dye (Applied Biosystems; Thermo Fisher Scientific, Inc.). The samples underwent a denaturation step $\left(95^{\circ} \mathrm{C}\right.$ for $\left.6 \mathrm{~min}\right)$, followed by 42 amplification cycles $\left(95^{\circ} \mathrm{C}\right.$ for $30 \mathrm{sec}, 60^{\circ} \mathrm{C}$ for $50 \mathrm{sec}$ and $72^{\circ} \mathrm{C}$ for $\left.70 \mathrm{sec}\right)$, melting step $\left(95^{\circ} \mathrm{C}\right.$ for $1 \mathrm{~min}, 65^{\circ} \mathrm{C}$ for $1 \mathrm{~min}$ and $95^{\circ} \mathrm{C}$ continuous acquisition) and cooling $\left(37^{\circ} \mathrm{C}\right.$ for $1 \mathrm{~min}$ ). The relative quantity of cDNA was estimated by the $2^{-\Delta \Delta \mathrm{Cq}}$ method (31). The following primers were purchased from East Port Praha s.r.o. (Prague, Czech Republic): $\beta$-actin (ACTB) forward, 5'-CATTGCTGACAGGATGCAGAAGG-3' and reverse, 5'-TGCTGGAAGGTGGACAGTGAGG-3'; p21 forward, 5'-CAGATCCACAGCGATATCCA-3' and reverse, 5'-ACGGGACCGAAGAGACAAC-3'. The final concentration of the primers used was $1 \mu \mathrm{M}$. Fold changes in transcript levels were calculated relative to $\beta$-actin, which was used as the endogenous reference gene control. The relative expression in the control group was normalized to 1 . All samples were run in triplicate.

Enzyme-linked immunosorbent assay (ELISA). The protein levels of murine GRO $\alpha$ (cat no. DY453; R\&D Systems, Inc.) and IL-6 (cat no. 555240; BD Biosciences, San Diego, CA, USA) were detected in the supernatants of non-senescent and senescent TC-1 and B16 cells using high-sensitivity ELISA kits. Supernatants were prepared by 4 -day cell treatments at $37^{\circ} \mathrm{C}$ followed by a medium change and another $24 \mathrm{~h}$ of cell cultivation $\left(1.5 \times 10^{6}\right.$ cells $\left./ 5 \mathrm{ml}\right)$ in fresh medium. Experiments were performed according to the manufacturer's protocols.

Estimation of DNA replication. B16 and TC-1 cells were driven to 'primary' or 'bystander' senescence as described above. DNA replication was estimated by 5-ethynyl-2'-deoxyuridine (EdU) incorporation with Click-iT Plus EdU Alexa Fluor 647 Flow Cytometry Assay kit (Invitrogen; Thermo Fisher Scientific, Inc.) according to the manufacturer's protocol. On day 4 of the treatments, cells were incubated with $10 \mu \mathrm{M}$ EdU for $24 \mathrm{~h}$ at $37^{\circ} \mathrm{C}$. For the Click-iT reaction, cells were washed once with PBS and detached using trypsin. Furthermore, the cells were washed twice in PBS and resuspended in fresh PBS. EdU incorporation was measured using a BD FACSVerse ${ }^{\mathrm{TM}}$ flow cytometer (BD Biosciences) and the data were analysed using FlowJo 10 software (FlowJo LLC, Ashland, OR, USA).

Flow cytometry. Cell size and granularity of 20,000 cells was evaluated by analysing the side scattering (SSC) and forward scattering (FSC) of the unstained cells. FSC intensity is associated with the cell size, whereas SSC corresponds with the cell refractive index that depends on the cell granularity (32). The data were presented as FSC-A and SSC-A plots, where -A, also known as the pulse area, represents the integral of the height and width of the pulse. Pulse area is considered to be more accurate when compared with the pulse height $(-\mathrm{H})$ value only. Cell size and granularity were measured using a BD FACSVerse ${ }^{\mathrm{TM}}$ flow cytometer (BD Biosciences). Cell autofluorescence was measured in the APC channel. Data were analysed using FlowJo 10 software (FlowJo LLC), as described below.

Immunofluorescence staining. TC-1 and B16 (control and treated) cells were grown on glass coverslips coated with $0.01 \%$ poly-L-lysine solution (Sigma-Aldrich; Merck KGaA) for $15 \mathrm{~min}$ at room temperature. Senescence was induced by DTX or IFN $\gamma+$ TNF $\alpha$, as described above. On day 4 of the treatment, cells were fixed with $4 \%$ formaldehyde and permeabilized with $0.1 \%$ Triton X-100 in two consecutive steps, each for $15 \mathrm{~min}$ at room temperature. Subsequently, the cells were washed once with PBS, blocked in 10\% FBS/PBS for $30 \mathrm{~min}$ at room temperature, stained with diluted primary antibodies at 1:100 for $1 \mathrm{~h}$ at room temperature and washed twice with PBS/0.1\% Tween-20. Following washing with PBS, cells were incubated with diluted secondary antibody at 1:500 for $1 \mathrm{~h}$ at room temperature. To counterstain nuclei, coverslips were mounted in Mowiol containing 4',6-diamidine-2-phenylindole at room temperature (Sigma-Aldrich; Merck KGaA). Cells were examined using a fluorescence microscope at a magnification of x63 (Leica DMI6000; Leica Microsystems GmbH). The antibodies used were as follows: Phospho-Ser139 of histone $\mathrm{H} 2 \mathrm{~A}$ histone family, member $\mathrm{X}(\gamma \mathrm{H} 2 \mathrm{AX})$ rabbit monoclonal antibody (cat no. 9718; Cell Signaling Technology, Inc.) and goat anti-rabbit immunoglobulin $\mathrm{G}$ antibody conjugated with Alexa 488 (cat no. A11034; Invitrogen; Thermo Fisher Scientific, Inc.).

Western blotting. TC-1 and B16 (control as well as treated) cells were washed twice with PBS and harvested with sample lysis buffer (20 mM HEPES, $50 \mathrm{mM} \mathrm{NaCl}, 1 \% \mathrm{mM}$ EDTA, $0.1 \%$ Triton $\mathrm{X}-100$ and $10 \%$ glycerol in double distilled water) supplemented with a cOmplete ${ }^{\mathrm{TM}}$ ULTRA Tablets, mini, EASYpack Protease Inhibitor cocktail (cat no. 05892970001; Roche Diagnostics GmbH, Mannheim, Germany) and PhosSTOP phosphatase inhibitor cocktail (cat no. 04906837001; Roche Diagnostics GmbH). Concentration of proteins was determined by the bicinchoninic acid method (Pierce; Thermo Fisher Scientific, Inc.). DTT (100 mM) and $0.01 \%$ bromphenol blue was added to lysates prior to separation by $12 \%$ SDS-PAGE. Equal amounts of protein $(35 \mu \mathrm{g})$ were loaded into each well. Proteins were electrotransferred onto a nitrocellulose membrane using wet transfer. The membrane was blocked in $10 \%$ nonfat dry milk diluted in $0.1 \%$ Tween/PBS for $1 \mathrm{~h}$ at room temperature, and detected by specific antibodies combined with horseradish peroxidaseconjugated secondary antibody (anti-rabbit; cat. no. 1706515; Bio-Rad Laboratories, Inc., Hercules, CA, USA). The membrane was incubated with primary antibodies (anti-p21 and anti-GAPDH) overnight at $4^{\circ} \mathrm{C}$ and secondary antibody for $1 \mathrm{~h}$ at room temperature. Peroxidase activity was detected by SuperSignal West Dura Extended Duration Substrate (cat. no. 34075; Pierce; Thermo Fisher Scientific, Inc.). GAPDH was used as a loading control. The following primary antibodies were used: Anti-mouse p21 rabbit monoclonal antibody (1:1,000; cat. no. ab109199; Abcam, Cambridge, UK) and anti-mouse GAPDH rabbit monoclonal antibody (1:1,000; cat. no. 2118S; Cell Signaling Technology, Inc.). Protein signals were detected by developing the blots with X-ray film (Agfa Healthcare Corporation, Greenville, SC, USA) on X-ray film 
A TC-1

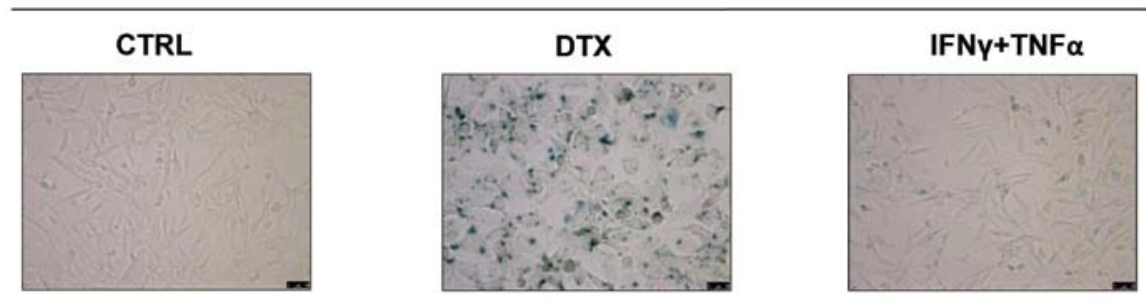

B

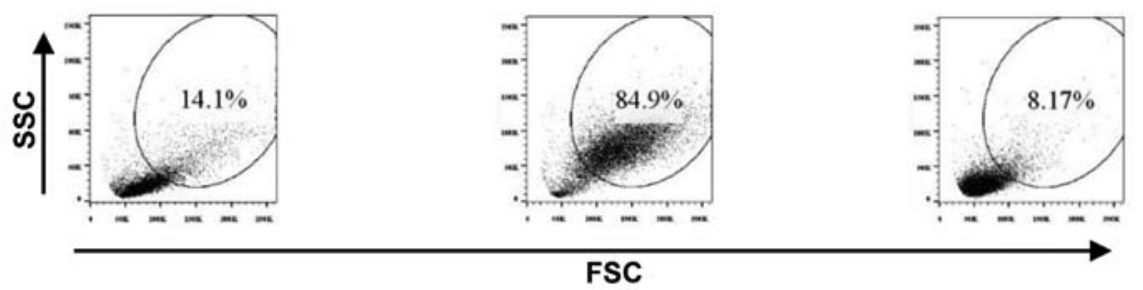

C

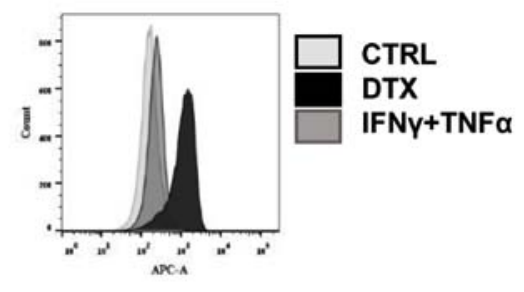

E

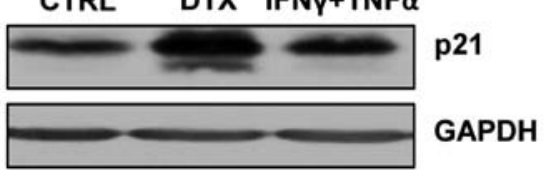

D

p21

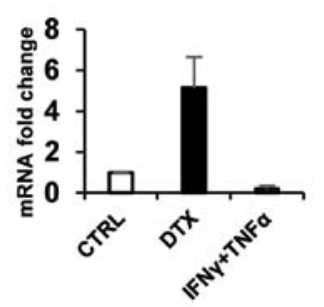

Figure 1. DTX induces senescence in TC-1 cells. (A) Senescence-associated $\beta$-galactosidase activity in TC-1 cells treated with DTX or IFN $\gamma+$ TNF $\alpha$ for 4 days. (B) The size and granularity of control or IFN $\gamma+$ TNF $\alpha$-treated senescent TC-1 cells was determined by forward and side scatter flow cytometry analysis. (C) Autofluorescence of the TC-1 control cells is presented in light grey, DTX-treated in black and IFN $\gamma+$ TNF $\alpha$-treated in grey. (D) Reverse transcription-quantitative polymerase chain reaction quantification of $\mathrm{p} 21$ in control, DTX- and IFN $\gamma+$ TNF $\alpha$-treated TC- 1 cells. (E) Immunoblotting detection of mouse p21 in control, DTX- and IFN $\gamma+$ TNF $\alpha$-treated TC-1 cells harvested on day 4. GAPDH was used as a loading control. Representative results from at least three independent experiments are presented. Data are presented as the mean \pm standard deviation. CTRL, control cells; DTX, docetaxel; IFN $\gamma$, interferon $\gamma ;$ TNF $\alpha$, tumour necrosis factor $\alpha$; FSC, forward scattering; SSC, side scattering; 21 , p21 ${ }^{\text {Wafl }}$.

processor (Optimax 2010, Protec GmbH, Ottobrunn, Bavaria, Germany). X-ray films then were scanned (Epson Scan Perfection V700 Photo, Japan) and final data were edited by Adobe Photoshop CS6 (Adobe Inc., version 13).

In vivo experiments. $\mathrm{B} 6$ mice (8 per group) were transplanted on day 0 subcutaneously (s.c.) with control TC-1 or B16 cells $\left(3 \times 10^{4}\right)$, DTX-induced senescent TC-1/DTX or B16/DTX cells (in two doses: $3 \times 10^{4}$ and $3 \times 10^{5}$ ), IFN $\gamma+\mathrm{TNF} \alpha$-treated TC-1/IFN $\gamma+\mathrm{TNF} \alpha$ or B16/IFN $\gamma+\mathrm{TNF} \alpha$ cells $\left(3 \times 10^{4}\right.$ each). In the case of induction of 'bystander' senescence, B6 mice ( 8 per group) were transplanted on day 0 s.c. with control TC-1 and B16 cells $\left(3 \times 10^{4}\right)$, 'bystander' senescent TC-1/SM or B16/SM cells (in two doses: $3 \times 10^{4}$ and $3 \times 10^{5}$ ). Mice were observed twice a week and the size of the tumours was recorded. Two diameters of the tumours (largest diameter and perpendicular) were measured with a calliper and the tumour size was expressed as the tumour area $\left(\mathrm{cm}^{2}\right)$ by the following formula: Tumour area $\left(\mathrm{cm}^{2}\right)=$ largest diameter $(\mathrm{cm})$ x perpendicular diameter $(\mathrm{cm})$. The maximum tumour size in one direction was $1.8 \mathrm{~cm}$. Mice were sacrificed by cervical dislocation and $\mathrm{CO}_{2}$ asphyxiation.
Statistical analysis. For the statistical analyses of the in vitro experiments, statistical significance was determined by a two-tailed analysis of variance test and subsequently by Bonferroni multiple comparisons as a post-test using GraphPad Prism 5.04 (GraphPad Software, Inc., La Jolla, CA, USA). All experiments were performed in three independent replicates. For the evaluation of in vivo experiments, analysis of variance from the Number Cruncher Statistical System v.10 (NCSS, LLC, Kaysville, UT, USA) statistical package was utilized. The data were presented as the mean \pm standard deviation in the figures. $\mathrm{P}<0.05$ was considered to indicate a statistically significant difference.

\section{Results}

$D T X$ and IFN $\gamma+T N F \alpha$-mediated senescence induction in mouse tumour cell lines TC-1 and B16. First, the impact of DTX and IFN $\gamma$ in combination with IFN $\gamma+$ TNF $\alpha$ in terms of senescence induction on two tumour cell lines, TC-1 (Fig. 1) and B16 (Fig. 2) was examined. The two cell lines were sensitive to $7.5 \mu \mathrm{M}$ DTX treatment and became senescent subsequent to 4 days of incubation, as characterized by 
A

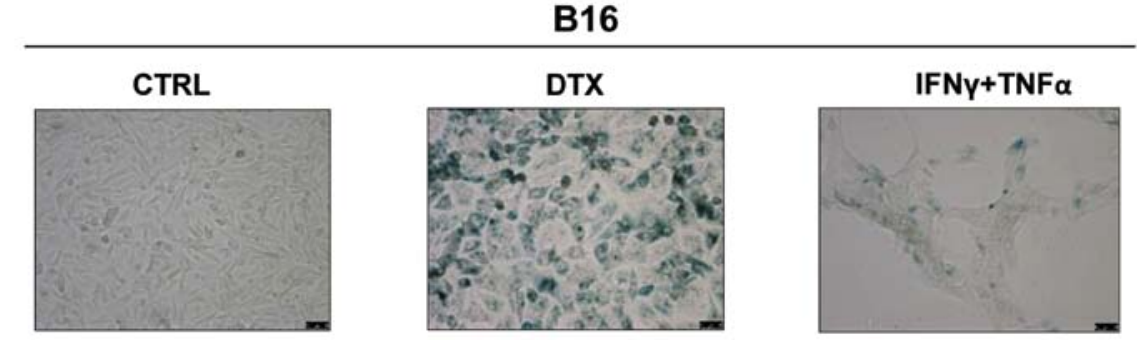

\section{B}

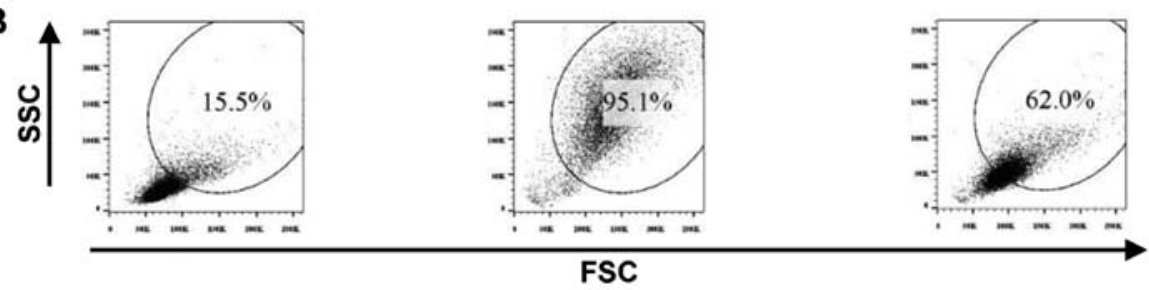

C

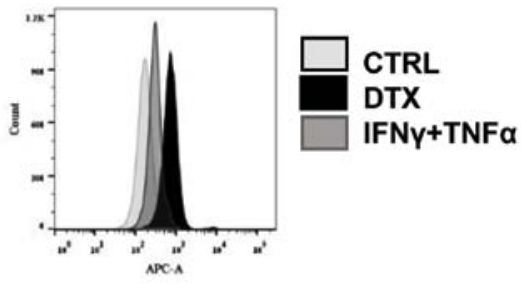

D

E

CTRL DTX IFNy+TNF $\alpha$
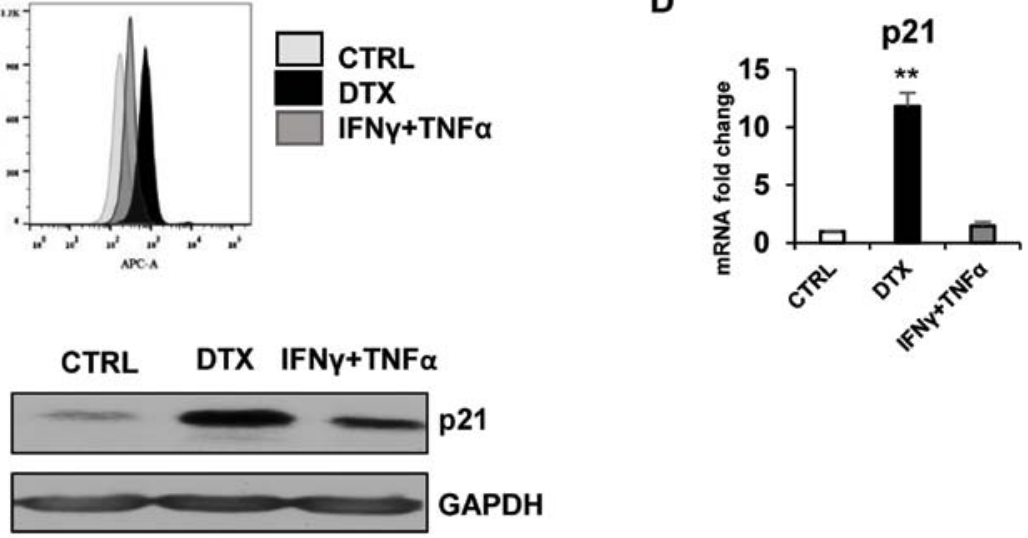

Figure 2. DTX induces senescence in the B16 cell line. (A) Senescence-associated $\beta$-galactosidase activity in B16 cells treated with DTX or IFN $\gamma+$ TNF $\alpha$ for 4 days. (B) The size and granularity of control or IFN $\gamma+$ TNF $\alpha$-treated, senescent B16 cells was determined by forward and side scatter flow cytometry analysis. (C) Autofluorescence of the B16 control cells is presented in light grey, DTX-treated in black and IFN $\gamma+$ TNF $\alpha$-treated in grey. (D) Reverse transcription-quantitative polymerase chain reaction quantification of p21 in control, DTX- and IFN $\gamma+\mathrm{TNF} \alpha$-treated B16 cells. (E) Immunoblotting detection of mouse p21 in control, DTX- and IFN $\gamma+$ TNF $\alpha$-treated B16 cells harvested on day 4. GAPDH was used as a loading control. Representative results from at least three independent experiments are presented. Data are presented as the mean \pm standard deviation. ${ }^{* *} \mathrm{P}<0.01$ vs. CTRL. CTRL, control cells; DTX, docetaxel; IFN $\gamma$, interferon $\gamma$; TNF $\alpha$, tumour necrosis factor $\alpha$; FSC, forward scattering; SSC, side scattering; p21, p21 ${ }^{\text {Waf1 }}$; B16, B16F10 cell line.

increased SA- $\beta$-galactosidase activity and typical phenotypic and morphological changes of the cells (Figs. 1A and 2A). In comparison with the DTX treatment, no indicators of senescence were observed in TC-1 cells following incubation with IFN $\gamma+$ TNF $\alpha$ (Fig. 1C-E). IFN $\gamma+$ TNF $\alpha$-treated B16 cells were larger, flattened and elongated (spindle-shaped) compared with the controls (Fig. 2A). Additionally, the cellular senescent phenotype was confirmed by FACS measurement of the size and granularity of TC-1 and B16 cells. In the two tumour cell lines, a significant $>5$-fold increase of SSC and FSC high-gated cells was detected [statistical analysis from three independent experiments: TC-1 $13.2 \pm 1.92$ vs. TC-1/DTX $85.33 \pm 1.99(\mathrm{P}<0.001) ; \mathrm{B} 1615.87 \pm 1.88$ vs. B16/DTX $94.93 \pm 2.65$ $(\mathrm{P}<0.01)$; the numbers correspond to the percentage of gated cells, Figs. 1B and 2B] following DTX treatment compared with the control. A 4-fold increase of SSC and FSC high-gated cells was detected following IFN $\gamma+\mathrm{TNF} \alpha$ treatment in $\mathrm{B} 16$ but not in TC-1 cells [TC-1 13.2.33 \pm 1.92 vs. TC-1/IFN $\gamma+\mathrm{TNF} \alpha$ $8.8 \pm 0.64(\mathrm{P}>0.05) ; \mathrm{B} 1615.87 \pm 1.88$ vs. $\mathrm{B} 16 / \mathrm{IFN} \gamma+\mathrm{TNF} \alpha$ $64.23 \pm 7.70(\mathrm{P}<0.05)$; Figs. 1B and $2 \mathrm{~B}]$. As senescent cell autofluorescence is considered to be a marker of senescence, in the present study, autofluorescence was evaluated in TC-1 and B16 cells following DTX treatment (Figs. 1C and 2C). In comparison with DTX-treated cells, TC-1 cells following IFN $\gamma+\mathrm{TNF} \alpha$ treatment did not exhibit increased autofluorescence, compared with the control cells; whereas B16/IFN $\gamma+$ TNF $\alpha$-treated cells exhibited higher autofluorescence compared with the control or DTX-treated cells. An increase in $\mathrm{p} 21$ gene expression, typical of cell stress/senescence, was detected by RT-qPCR in DTX-treated TC-1 and B16 cells (Figs. 1D and 2D) and was significant in B16 cells $(\mathrm{P}<0.01)$, but not in IFN $\gamma+\mathrm{TNF} \alpha$-treated $\mathrm{B} 16$ and TC-1 cells Immunoblotting detection of mouse p21 indicated increased protein expression in DTX-treated TC-1 and B16 cells and also a moderate increase in IFN $\gamma+\mathrm{TNF} \alpha$-treated B16 cells, but not in TC-1 cells (Figs. 1E and 2E).

Furthermore, TC-1 and B16 tumour cell proliferation was evaluated in vitro at different time points (day 4 and 7) following DTX and IFN $\gamma+$ TNF $\alpha$ treatments. Following 4 days of treatments in TC-1 cells (Fig. 3A), a significant increase in the number of tumour cells was observed in the control and $\mathrm{IFN} \gamma+\mathrm{TNF} \alpha$-treated groups compared with day $0(\mathrm{P}<0.001)$, 
A

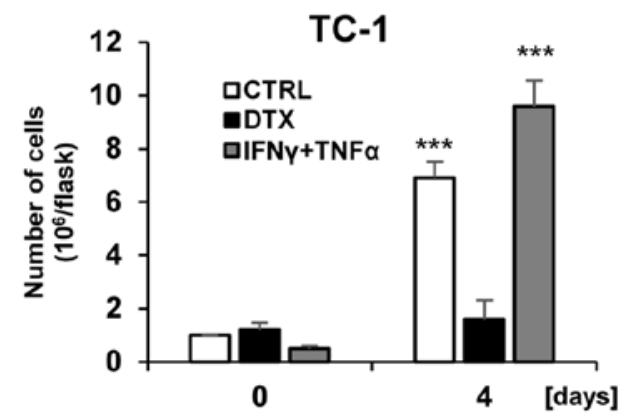

C

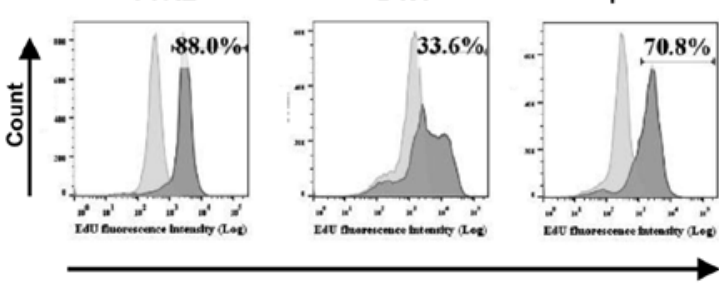

EdU fluorescence intensity $(\log )$

E

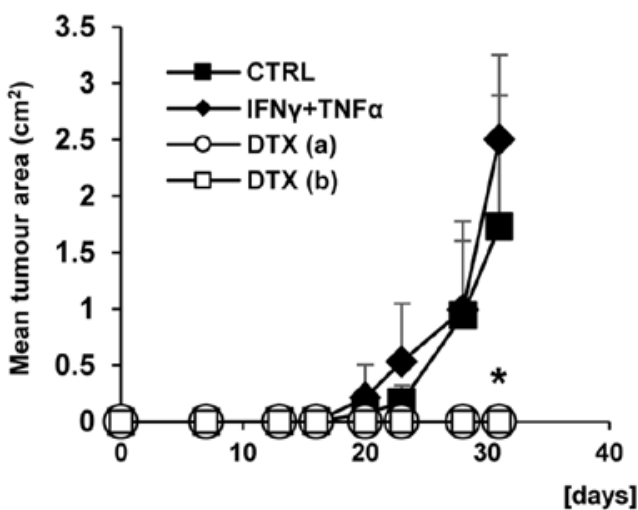

B

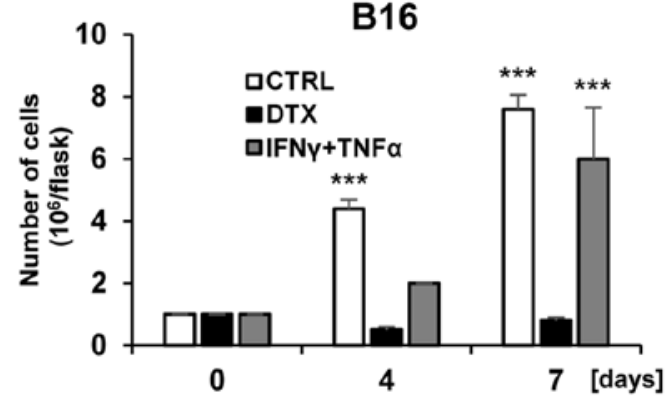

D

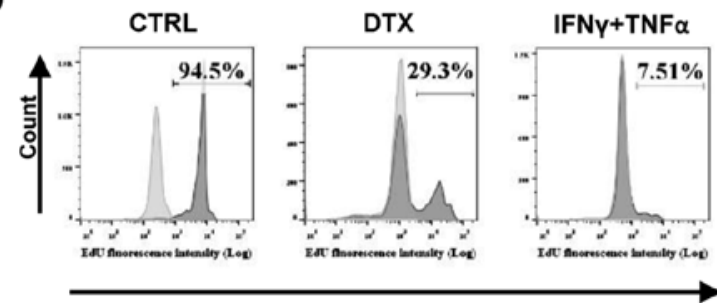

EdU fluorescence intensity $(\log )$

$\mathbf{F}$

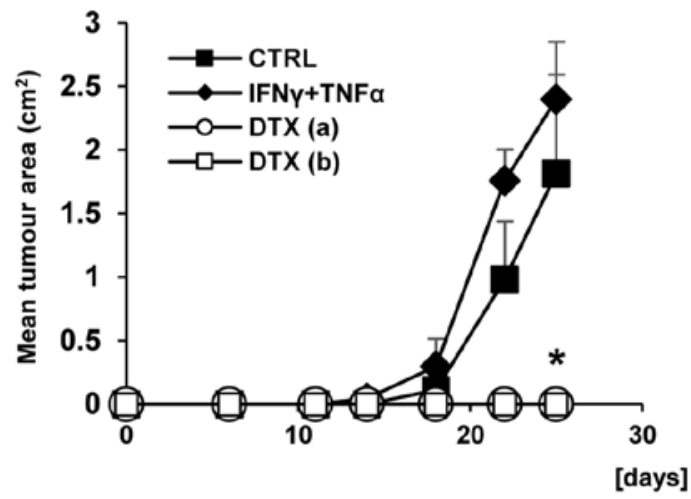

Figure 3. Analysis of TC-1 and B16 cell proliferation during 'primary' induction. (A) TC-1 and (B) B16 cells were treated with DTX and IFN $\gamma+$ TNF $\alpha$. Cell proliferation was determined by counting the cell number on days 4 (TC-1 and B16) and 7 (B16 only). Control cells were passaged on day 4 . Data are presented as the mean \pm standard deviation. ${ }^{* * * *} \mathrm{P}<0.001$ vs. day 0 . For EdU incorporation: Cells were driven to senescence by 4-day treatments with DTX or $\mathrm{IFN} \gamma+\mathrm{TNF} \alpha$, and then incubated with $10 \mu \mathrm{M}$ EdU for $24 \mathrm{~h}$. Click-iT reaction was performed on fixed cells, and FACS analysis was performed to determine the fraction of proliferating (C) TC-1 and (D) B16 cells in the treated and control samples. Representative results from three independent experiments are presented. Mice (8 per group) were transplanted subcutaneously on day 0 with (E) TC-1 and (F) B16 cells $\left(3 \times 10^{4}\right)$, with IFN $\gamma+\mathrm{TNF} \alpha$-treated cells $\left(3 \times 10^{4}\right)$ or with senescent DTX-treated cells at the doses $3 \times 10^{4}$ [B16 or TC-1/DTX(a)] or $3 \times 10^{5}$ [B16 or TC-1/DTX(b)] tumour cells and the tumour growth was monitored The experiment was repeated two times with similar results. " $\mathrm{P}<0.05$ [TC-1 or TC-1/IFN $\gamma+\mathrm{TNF} \alpha$ vs. TC-1/DTX (a or b)]; [B16 or B16/IFN $\gamma+\mathrm{TNF} \alpha$ vs. B16/ DTX (a or b); analysis of variance]. CTRL, control cells; DTX, docetaxel; IFN $\gamma$, interferon $\gamma$; TNF $\alpha$, tumour necrosis factor $\alpha$; B16, B16F10 cell line.

whereas no cell proliferation was detected in DTX. In B16 cells, a loss of proliferation was detected following DTX treatment for 4 days, but not following IFN $\gamma+$ TNF $\alpha$ treatment, where the number of proliferative cells was increased compared with day $0(\mathrm{P}<0.01)$ but did not reach the number in the control group (Fig. 3B). In addition, the medium containing DTX and IFN $\gamma+$ TNF $\alpha$ was removed and the cells were cultured in fresh medium until day 7. Then, the number of proliferating B16 cells was examined. It was identified that the number of tumour cells pretreated with IFN $\gamma+\mathrm{TNF} \alpha$ was comparable to the control group, and was significantly increased compared with day $0(\mathrm{P}<0.01)$. In the case of DTX pretreated B16 cells, the cell cycle remained arrested.

To evaluate the loss of proliferation associated with senescence development, the discontinuation of DNA replication was assayed by the detection of EdU incorporation into DNA. Only limited subsets of EdU-positive cells were observed in TC-1 and B16 cell populations following cultivation with DTX, as measured by FACS analysis (Fig. 3C and D). Proliferative arrest was also detected in IFN $\gamma+\mathrm{TNF} \alpha$-treated B16 cells, but not in IFN $\gamma+$ TNF $\alpha$-treated TC- 1 cells. Average percentages (from three measurements) of EdU-positive cells and the differences between experimental groups were as follows: TC-1 82.9 \pm 4.50 vs. TC/DTX 35.2 $\pm 5.28(\mathrm{P}<0.05)$;

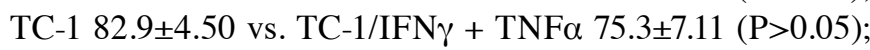
B16 94.73 \pm 1.96 vs. B16/DTX 26.43 $\pm 7.80(\mathrm{P}<0.01)$ and B16 $94.73 \pm 1.96$ vs. B16/IFN $\gamma+$ TNF $\alpha$ 7.95 $\pm 0.42(\mathrm{P}<0.001)$.

To verify the in vitro cessation of proliferation in senescent cells, the growth of senescent tumour cells was evaluated in vivo. B6 mice were injected with DTX-induced senescent cells in the same dose as a control testing dose for proliferating cells $\left(3 \times 10^{4}\right)$ and a 10 -fold dose $\left(3 \times 10^{5}\right)$. Mice were also injected with the cells that underwent treatment with IFN $\gamma+$ TNF $\alpha\left(3 \times 10^{4}\right)$. No tumour growth was observed 
A

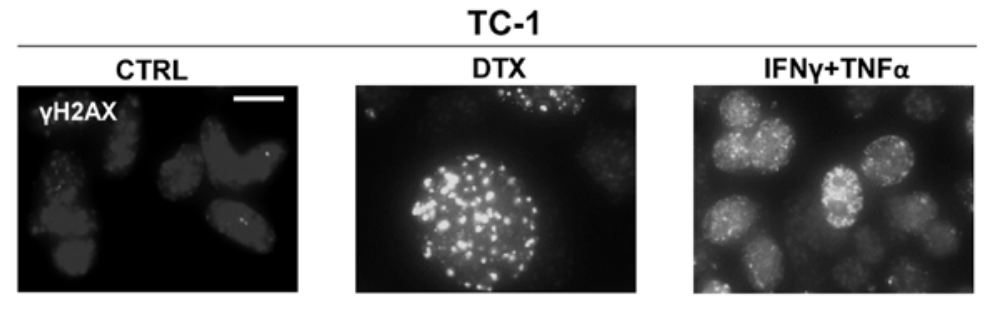

B

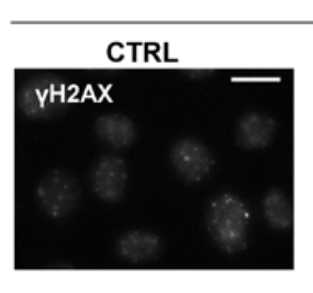

B16

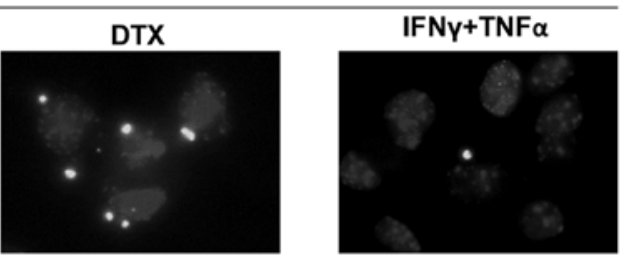

C

TC-1

D
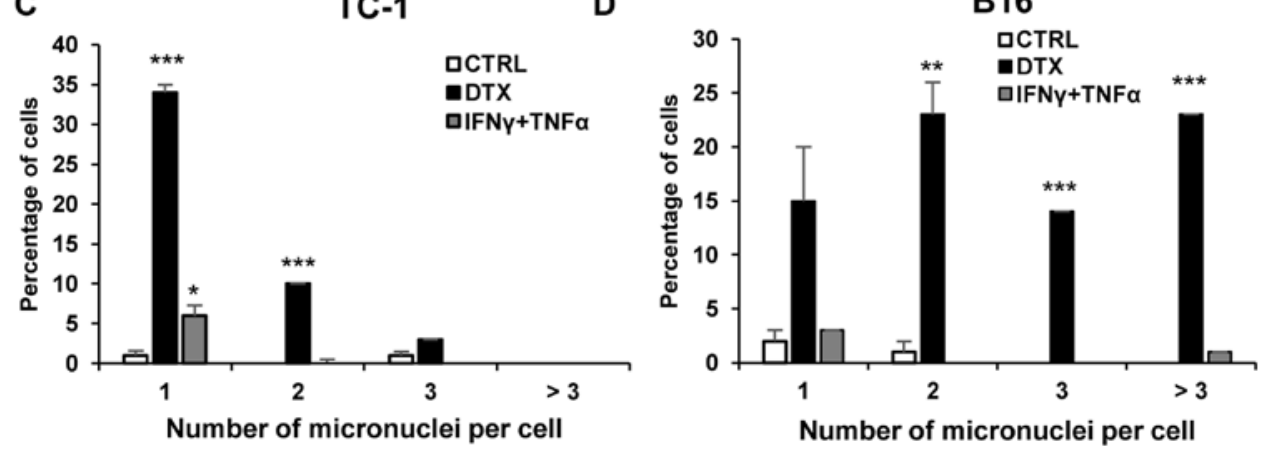

Figure 4. DNA damage detection in TC-1 and B16 tumour cell lines. To detect DNA damage, control, DTX- or IFN $\gamma+$ TNF $\alpha$-treated (A) TC-1 and (B) B16 cells were stained with phosphoSer139 H2A histone family, member X antibody and mounted with Mowiol containing 4',6-diamidine-2-phenylindole. Scale bar, $20 \mu \mathrm{m}$. Percentage of cells with 1, 2, 3 or more micronuclei in (C) TC-1 and (D) B16 cells treated with DTX or IFN $\gamma+$ TNF $\alpha$ was quantified. Data are presented as the mean \pm standard deviation. ${ }^{*} \mathrm{P}<0.05,{ }^{* *} \mathrm{P}<0.01$ and ${ }^{* * * *} \mathrm{P}<0.001$ vs. CTRL. A total of 100 cells were analysed in each experimental group. $\mathrm{CTRL}$, control cells; DTX, docetaxel; IFN $\gamma$, interferon $\gamma$; TNF $\alpha$, tumour necrosis factor $\alpha$; B16, B16F10 cell line.

following the injection of DTX-treated senescent TC-1 and B16 cells $(\mathrm{P}<0.05$ compared with the controls injected with untreated cells and harbouring growing tumours). On the other hand, TC-1, as expected, in addition to B16 cells, did not exhibit tumour growth arrest in vivo following treatment with immunostimulatory cytokines. The differences in tumour growth rates were not significant compared with the growth of tumours following the injection of mice with proliferating tumour cells. This indicates that following treatment with IFN $\gamma+\mathrm{TNF} \alpha, \mathrm{B} 16$ cells underwent an only temporary loss of proliferation (Fig. 3E and F).

Induction of cellular senescence is associated with DNA damage response. The presence of DNA damage foci positive for $\gamma \mathrm{H} 2 \mathrm{AX}$, a factor participating in DNA double-strand break sensing and repair, was investigated by immunofluorescent staining. In the majority of the DTX-treated TC-1 (Fig. 4A) and B16 cells (Fig. 4B) an increase of $\gamma \mathrm{H} 2 \mathrm{AX}$ foci was detected with persistent DNA damage response. Following treatment with IFN $\gamma+$ TNF $\alpha$, only a small number of TC- 1 and B16 cells exhibited a mild increase in $\gamma \mathrm{H} 2 \mathrm{AX}$ foci compared with the control cells. Quantification analysis indicated an increase in the number of micronuclei in TC-1 and B16 cells treated with DTX compared with control cells, with a significantly greater percentage of TC-1 cells with 1 or 2 micronuclei $(\mathrm{P}<0.001)$ and $\mathrm{B} 16$ cells with $2(\mathrm{P}<0.01)$ or 3 or more micronuclei $(\mathrm{P}<0.001)$ compared with the control cells (Fig. 4C and D).
A significantly greater percentage of TC-1 cells treated with IFN $\gamma+\mathrm{TNF} \alpha$ had 1 micronuclei per cell compared with control cells $(\mathrm{P}<0.05$; Fig. $4 \mathrm{C})$. More than three micronuclei were detected in B16 cells only (Fig. 4D).

Senescent cells produced IL-6 and GRO $\alpha$ cytokines. To analyse the production of selected cytokines (GRO $\alpha$ and IL-6) by senescent tumour cells, supernatants were prepared and analysed by ELISA. A significant increase in secreted GRO $\alpha$ was observed following DTX treatment in TC-1 cells compared with control cells $(\mathrm{P}<0.01$; Fig. 5A). Significantly higher levels of IL-6 $(\mathrm{P}<0.001)$ and GRO $\alpha(\mathrm{P}<0.05)$ were detected in IFN $\gamma+\mathrm{TNF} \alpha$-treated B16 cells compared with control cells, while the secretion of IL- 6 following DTX treatment was not established, although the levels of GRO $\alpha$ in B16 cells following DTX treatment were significantly increased compared with the control cells $(\mathrm{P}<0.01)$ (Fig. 5B). Notably, IL-6 levels in B16 cells were substantially lower, as compared with TC- 1 cells. IL- 6 was also induced in TC- 1 cells upon IFN $\gamma+$ TNF $\alpha$ treatment that did not induce genotoxic stress. This was expected considering that IL-6 is regulated through nuclear factor- $\kappa \mathrm{B}$, which is activated by $\mathrm{TNF} \alpha$ (33)

Conditioned medium from DTX-treated senescent tumour cell culture was able to induce 'bystander' senescence in TC-1 and $B 16$ cell lines. To analyse the 'bystander' phenomenon of SASP in tumour cells that were driven to senescence, murine TC-1 
A

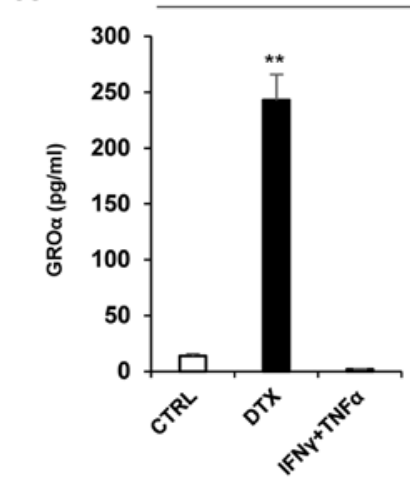

B

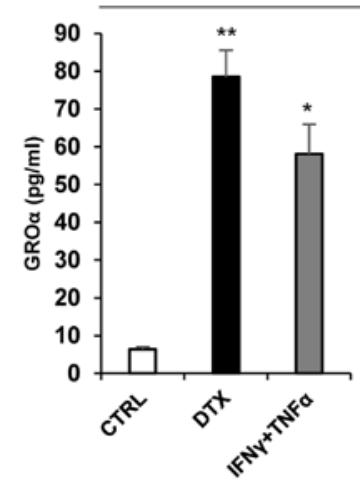

B16
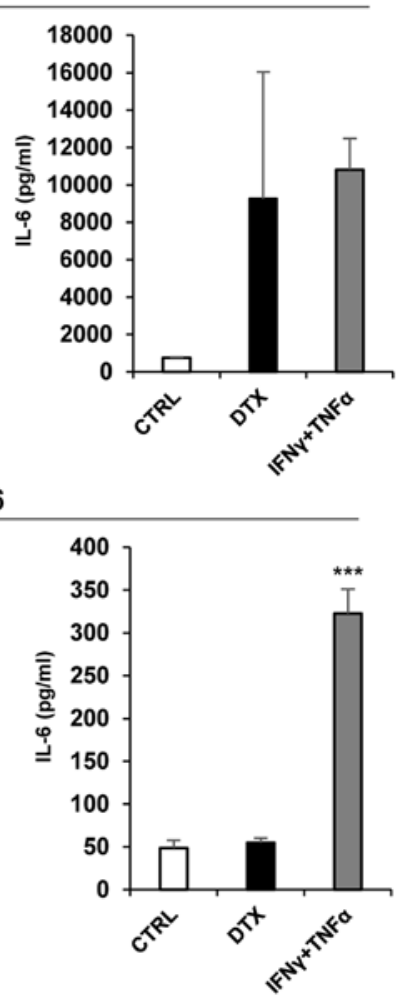

Figure 5. Secretion of IL-6 and GRO $\alpha$ by murine TC-1 and B16 tumour cell lines. Enzyme-linked immunosorbent assay of IL- 6 and GRO $\alpha$ in supernatants of (A) TC-1 and (B) B16 cells treated with DTX and IFN $\gamma+$ TNF $\alpha$. Supernatants were tested in triplicate and the results from three independent experiments are presented as the mean \pm standard deviation. ${ }^{* * *} \mathrm{P}<0.001$, ${ }^{* *} \mathrm{P}<0.01$ and ${ }^{*} \mathrm{P}<0.05$ vs. CTRL. Asterisks correspond to comparisons between control and treated groups. CTRL, control cells; DTX, docetaxel IFN $\gamma$, interferon $\gamma$; TNF $\alpha$, tumour necrosis factor $\alpha$; B16, B16F10 cell line GRO $\alpha$, growth-regulated oncogene $\alpha$; IL-6, interleukin 6 .

and B16 cells were exposed to culture media partly enriched with conditioned media (1:1) from TC-1 and B16 cells that were driven to senescence by cultivation with $7.5 \mu \mathrm{M}$ DTX (SM). In the case of B16 cells, medium from IFN $\gamma+\mathrm{TNF} \alpha$-treated cells was also used (IFN $\gamma+\mathrm{TNF} \alpha$ medium). IFN $\gamma+\mathrm{TNF} \alpha$ medium from TC-1 cells was not tested since there was no proliferation arrest of 'primary' senescence following this treatment. For comparison, medium from parental untreated cells was also used (TM). The presence of senescent cells in cultures exposed to these media was assessed using established markers of cellular senescence. After 4 days of exposure, the culture medium conditioned by DTX-treated cells resulted in the increased activity of SA- $\beta$-galactosidase in TC- 1 and B16 cells (Figs. 6A and 7A) and the increased size and granularity of the tumour cells analysed by flow cytometry (Figs. 6B and 7B). The mean percentages (from three measurements) of SSC and FSC high-gated cells were as follows: TC-1 19.83 \pm 1.90 vs. TC-1/SM 83.27 \pm 0.59 (P<0.001); TC-1 $19.83 \pm 1.90$ vs. TC-1/TM 19.24.3 $\pm 1.49(\mathrm{P}>0.05)$; B16 13.83 \pm 0.57 vs. B16/SM 93.77 \pm 3.17 $(\mathrm{P}<0.001)$; B16 13.83 \pm 0.57 vs. B16/TM 18.2 $\pm 1.3(\mathrm{P}>0.05)$ and B16 13.83 \pm 0.57 vs. B16/IFN $\gamma+$ TNF $\alpha$ medium $4.84 \pm 0.47$ $(\mathrm{P}>0.05)$. Significantly elevated levels of $\mathrm{p} 21$ in SM-treated cells ( $\mathrm{P}<0.05$; Figs. $6 \mathrm{C}$ and $\mathrm{D}, 7 \mathrm{C}$ and $\mathrm{D})$ as compared with fresh medium and medium from untreated tumour cells were identified. By contrast, the medium conditioned with medium from IFN $\gamma+\mathrm{TNF} \alpha$-treated cells was unable to induce 'bystander' senescence. Generally, the patterns of these senescent markers observed in 'bystander' cells were similar to those in senescent cells.

'Bystander' senescent cells exhibit proliferation arrest. The number of proliferating TC-1 and B16 cells was determined during cultivation with SM and TM. The pattern of results was similar to that directly following DTX and IFN $\gamma+$ TNFa treatments. There was no proliferation of TC-1 and B16 cells cultivated with SM, whereas following the cultivation of B16 cell lines with TM, a significant loss of proliferation compared with the control day 0 was observed ( $\mathrm{P}<0.001$; Fig. $8 \mathrm{~A}$ and $\mathrm{B})$. In addition, TC-1 cells cultivated with TM proliferated in the same manner as the control proliferative cells. Similar to 'primary' senescent cells, the arrest of DNA replication in 'bystander' senescent cells was tested by incorporation of EdU (Fig. 8C and D). Decreased incorporation of EdU in the cells cultured in senescent medium compared with tumour medium from untreated cells was observed. The mean percentages (from three measurements) of EdU-positive cells and the differences between experimental groups were following: TC-1 $84.03 \pm 4.00$ vs. TC/SM 26.93 $\pm 3.28(\mathrm{P}<0.001)$; TC $-184.03 \pm 4.00$ vs. TC-1/TM $68.67 \pm 2.46$ (P>0.05); B16 93.67 \pm 2.46 vs. B16/SM $10.8 \pm 1.3(\mathrm{P}<0.001)$ and $\mathrm{B} 1693.67 \pm 2.46$ vs. B16/TM 54.5 \pm 5.65 $(\mathrm{P}<0.05)$. Next, the proliferative arrest of TC-1 and B16 cells cultivated with SM was also confirmed in vivo. For this purpose, B6 mice were injected with two doses of 'bystander' senescent cells, the same dose as the testing dose $\left(3 \times 10^{4}\right)$ and a 10 -fold dose $\left(3 \times 10^{5}\right)$. Notably, no tumour growth was observed in B6 mice following the injection of 'bystander' senescent TC-1 and B16 cells (Fig. 8E and F; P $<0.05$ compared with the controls injected with untreated cells and harbouring growing tumours). B16 cells treated with conditioned media from the IFN $\gamma+$ TNF $\alpha$ cells were not tested since no morphological changes or increased $\mathrm{p} 21^{\text {Waf1 }}$ expression were observed.

DNA damage response in 'bystander' senescent cells. It was investigated whether the conditioned senescent medium may induce DNA damage in a 'bystander' manner in TC-1 and B16 cells. Notably, there was an increase in the number of $\gamma \mathrm{H} 2 \mathrm{AX}$ foci following incubation of the cells with senescent medium (Fig. 9A and B). Quantification analysis indicated an increase in the number of micronuclei in the cells treated with SM in TC-1 and B16 cell lines compared with control cells (Fig. 9C and D). There was a significant increase in the percentage of TC-1 cells treated with SM with 1 micronucleus per cell compared with the control cells $(\mathrm{P}<0.01)$; and a significant increase in the percentage of B16 cells treated with SM with 1, 2, 3 or more micronuclei per cell compared with the control cells $(\mathrm{P}<0.01)$. TM medium resulted in an increase only in the group with 1 micronucleus per cell in the B16 cell line (Fig. 9D). This increase may be explained by the fact that TM, conditioned control cell medium, was obtained from the proliferating cancer cells culture. The secretome of proliferating tumour cells also harbors cytokines, chemokines and other soluble agents that may be genotoxic (1), and their concentration when the cells are cultured in the TM medium may be higher when compared with the cells cultured in fresh medium, although no senescence induction 
A

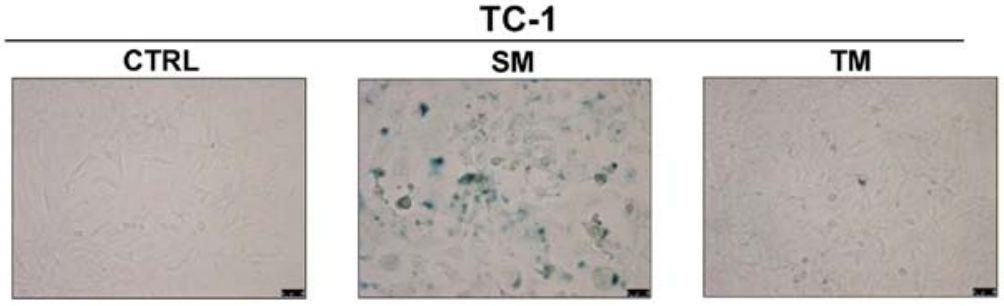

B
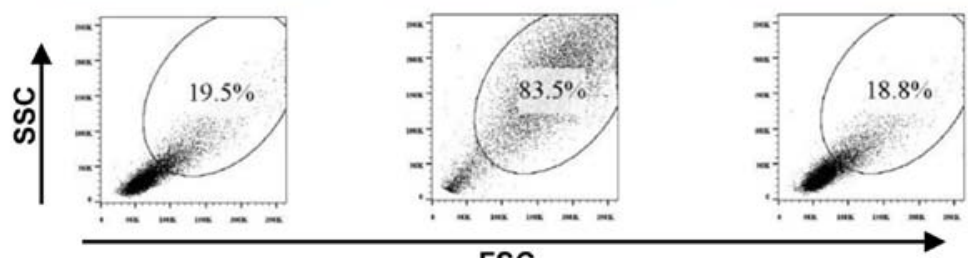

C

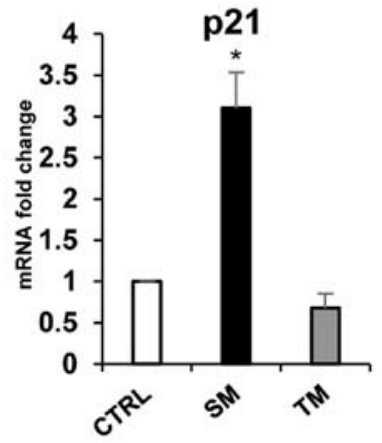

FSC

D

CTRL SM TM

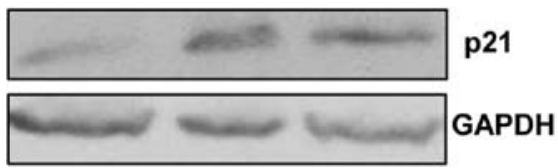

Figure 6. Induction of 'bystander' senescence in TC-1 tumour cells. (A) Senescence-associated $\beta$-galactosidase activity in TC- 1 cells cultured for 4 days in medium (SM), or proliferating cell medium (TM). (B) The size and granularity of control and senescent TC-1 cells was determined by forward and side scatter flow cytometry analysis. (C) Expression of p21 in TC-1 cells cultured for 4 days in different media (reverse transcription-quantitative polymerase chain reaction). (D) Immunoblotting detection of mouse p21 in TC-1 cells harvested on day 4 following cultivation in different media. GAPDH was used as a loading control. Data are presented as the mean \pm standard deviation. " $\mathrm{P}<0.05$ vs. CTRL. CTRL, control cells; SM, senescence medium; TM, tumour medium; FSC, forward scattering; SSC, side scattering; 21 , p21 ${ }^{\text {waf1 }}$.

A B16

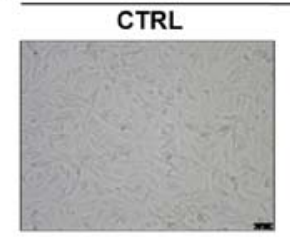

B
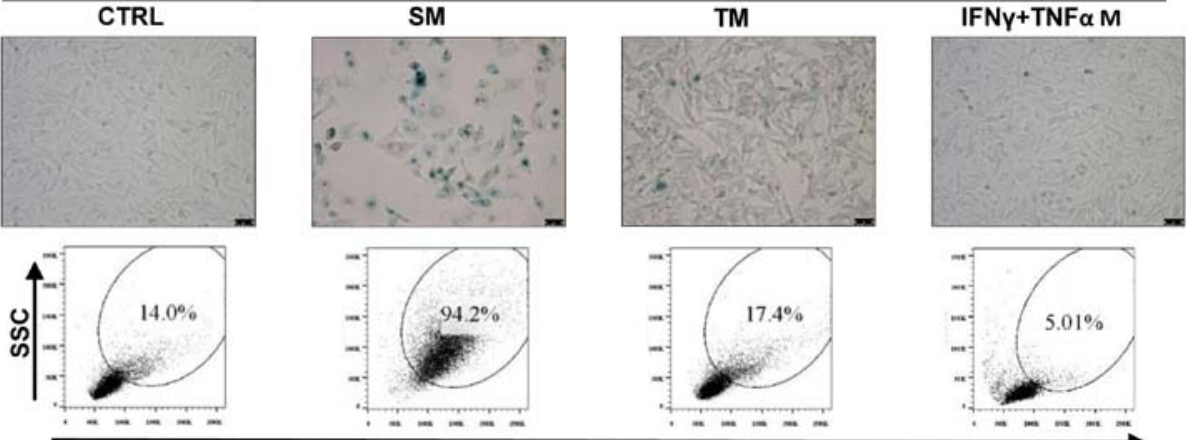

C

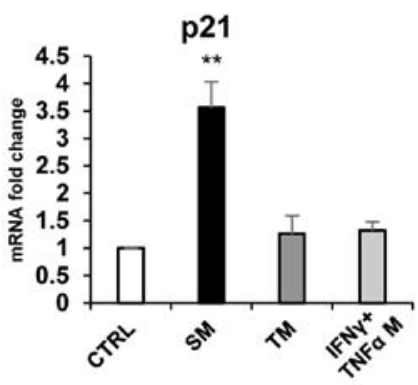

D
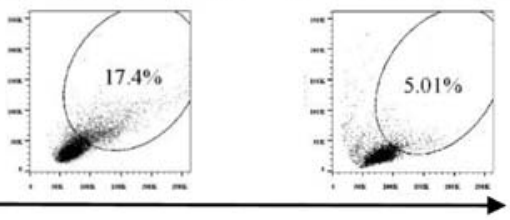

FSC

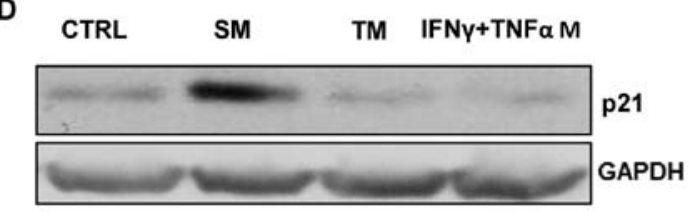

Figure 7. Induction of 'bystander' senescence in B16 tumour cells. (A) Senescence-associated $\beta$-galactosidase activity in B16 cells cultured for 4 days in the medium from DTX-treated cells (SM), IFN $\gamma+\mathrm{TNF} \alpha$-treated cells or proliferating cell medium (TM). (B) The size and granularity of control and senescent B16 cells was determined by forward and side scatter flow cytometry analysis. (C) Expression of p21 in B16 cells cultured for 4 days in different media (reverse transcription-quantitative polymerase chain reaction). (D) Immunoblotting detection of mouse p21 in B16 cells harvested on day 4 after cultivation in different media. GAPDH was used as a loading control. Data are presented as the mean \pm standard deviation. ${ }^{* *} \mathrm{P}<0.01$. CTRL, control cells; SM, senescence medium; TM, tumour medium; FSC, forward scattering; SSC, side scattering; p21, p21 ${ }^{\text {wafl }} ;$ B16, B16F10 cell line; IFN $\gamma$, interferon $\gamma ;$ TNF $\alpha$, tumour necrosis factor $\alpha$. 
A

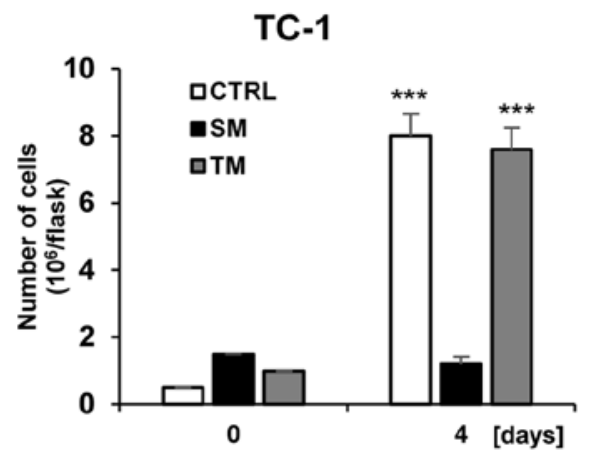

C

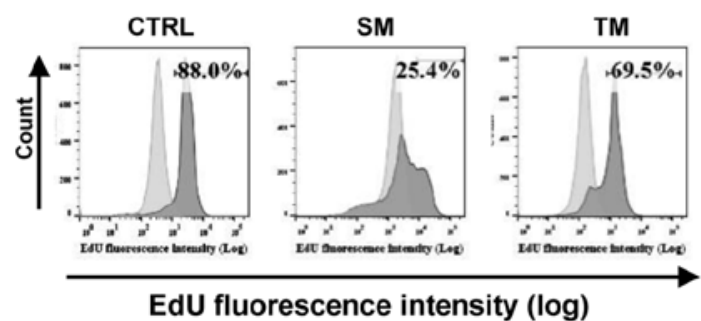

E

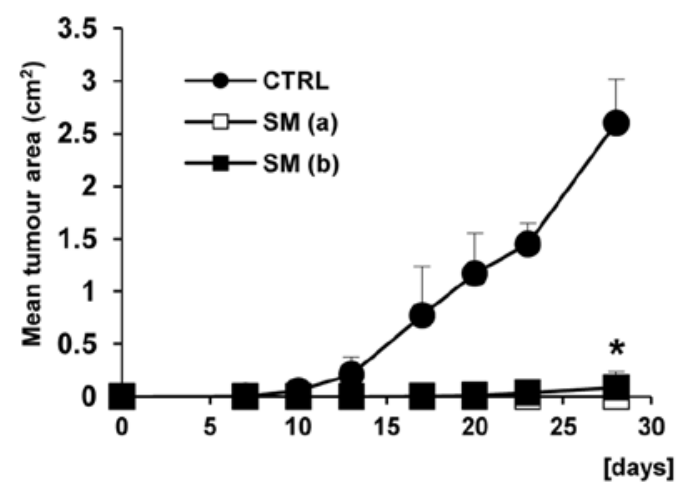

B

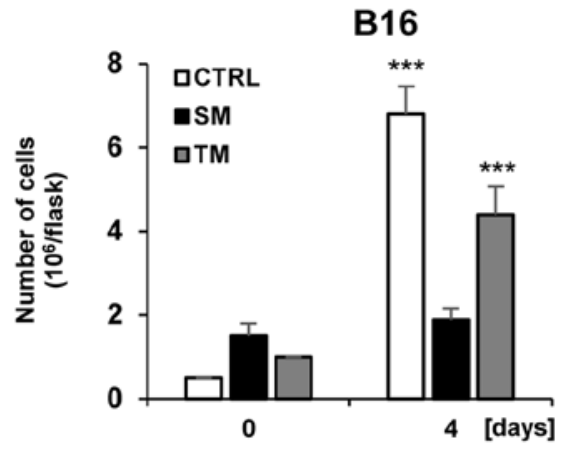

D
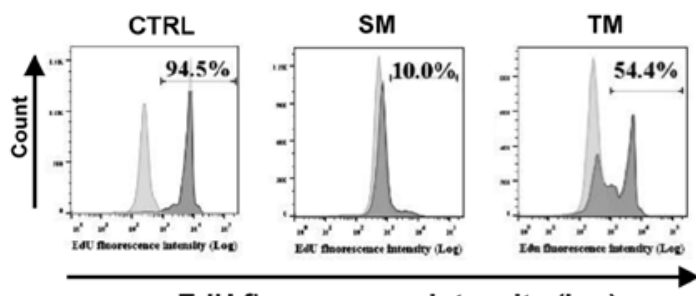

EdU fluorescence intensity (log)

$\mathbf{F}$

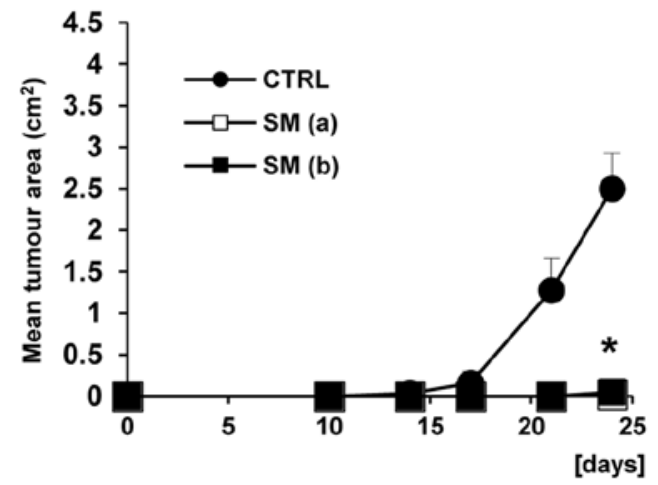

Figure 8. Analysis of TC-1 and B16 cell proliferation during 'secondary' induction. (A) TC-1 and (B) B16 cells were seeded in $25 \mathrm{~cm}^{2}$ cell culture flasks in triplicate and treated with SM and TM. Cell proliferation was determined by counting the cell number on day 4 . Data are presented as the mean \pm standard deviation. ${ }^{* * *} \mathrm{P}<0.001$ vs. day 0. For EdU incorporation: Cells were driven to senescence by cultivation for 4 days in the medium from DTX-treated cells (SM), proliferating cell medium (TM) and in fresh RPMI medium (CTRL), and then incubated with $10 \mu \mathrm{M}$ EdU for $2 \mathrm{~h}$. Click-iT reaction was performed on fixed cells and FACS analysis was performed to determine the fraction of proliferating (C) TC-1 and (D) B16 cells in the treated and control samples. Mice (8 per group) were transplanted subcutaneously on day 0 with (E) TC-1 and (F) B16 cells $\left(3 \times 10^{4}\right)$, with SM $\left(3 \times 10^{4}\right)$ [B16, TC-1/DTX(a)] or with SM at a density of $3 \times 10^{5}$ [B16, TC-1/DTX(b)] of tumour cells and the tumour growth was monitored. The experiment was repeated two times with similar results. "P<0.05 [TC-1 vs. TC-1/SM (a or b)]; [B16 or B16 vs. B16/SM (a or b); analysis of variance]. CTRL, control cells; SM, senescence medium; TM, tumour medium; B16, B16F10 cell line; DTX, docetaxel.

was observed in the present study. When compared with 'primary' senescence, the pattern of DNA damage in 'bystander' senescence was similar (Figs. 4 and 9). This indicated that 'bystander' senescence is induced by the DNA damage response pathway.

\section{Discussion}

The present study provides insight into the effects of two known inducers of cell stress and premature cellular senescence in a number of cell lines: DTX as a chemotherapeutic agent and a combination of Th1 cytokines, IFN $\gamma$ and TNF $\alpha(28,34)$. The differences in the senescence-associated phenotype between the cells that underwent these two treatments were compared. For the experiments, two murine cell lines were employed: TC-1 expressing human HPV16 E6 and E7 oncoproteins, and B16 melanoma cell lines. DTX has been demonstrated to induce senescence in TC-1 cells. p53 and retinoblastoma protein $(\mathrm{pRb})$ are inactivated in unperturbed TC- 1 cells by the presence of E3 ubiquitin ligases E6 and E7 (35), respectively, so it is unclear how proliferation arrest is mediated. p53 and $\mathrm{pRb}$ may be reactivated in TC-1 cells by the suppression of E6 and E7, which may be downregulated by genotoxic stress (35). This is analogous to HeLa cells exposed to genotoxic senescence-inducing conditions (36).

The present study particularly focused on the capability of cells to induce 'bystander' senescence through their secretome. The phenotype and biological behaviours of senescent cells correspond with the particular agents that induce cellular stress and subsequent premature senescence. These effects may be distinct in various cell lineages, reflecting the presence or absence of intact crucial signalling pathways.

DTX is a microtubule-stabilizing taxane that is widely used clinically for the treatment of breast and prostate cancer 
A

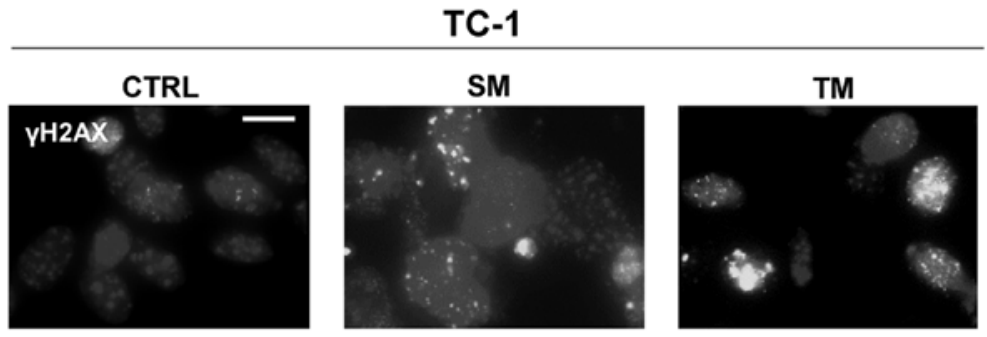

B

B16
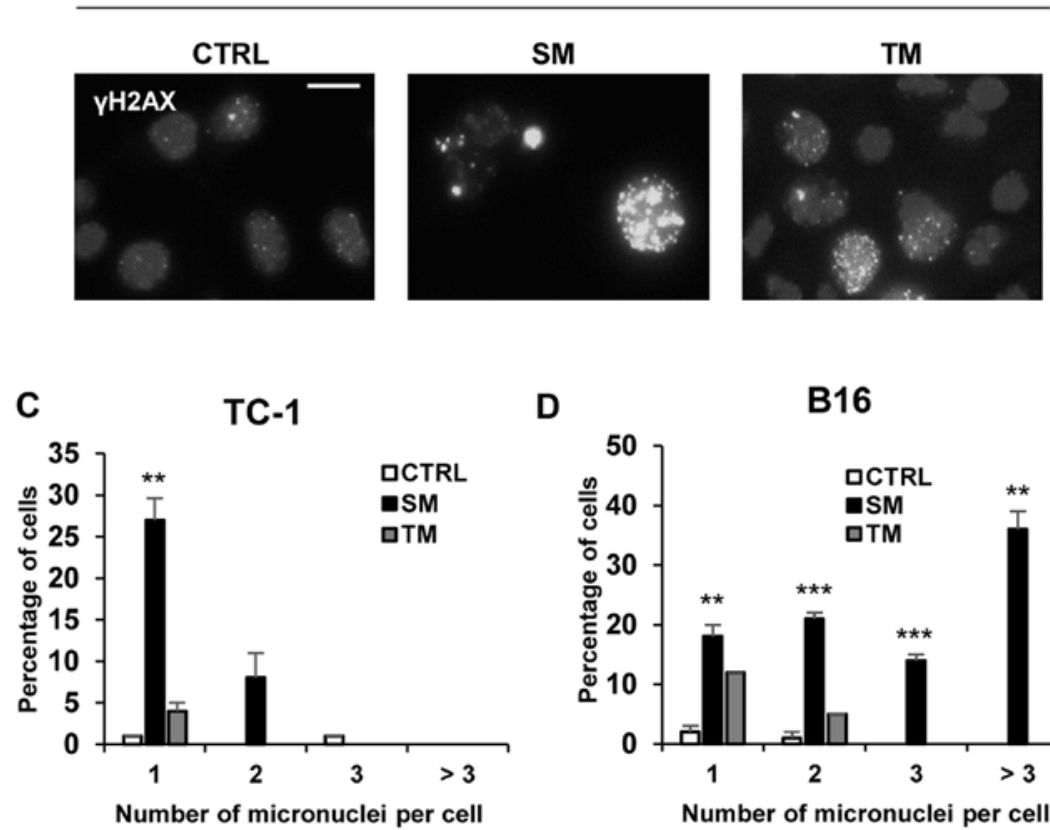

D

B16

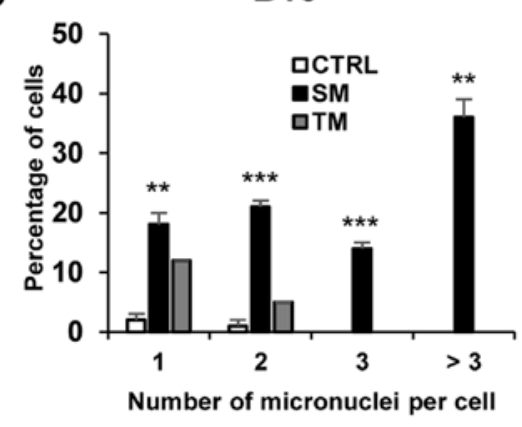

Figure 9. DNA damage response in 'bystander' cells treated with conditioned medium from senescent TC-1 and B16 cell lines. Immunofluorescence detection of phosphoSer139 H2A histone family, member X in (A) TC-1 and (B) B16 cells treated with relevant SM and TM medium for 4 days. Scale bar, $20 \mu \mathrm{m}$. Percentage of cells with 1,2,3 or more micronuclei in (C) TC-1 and (D) B16 cells treated with SM or TM was quantified. Data are presented as the mean \pm standard deviation. ${ }^{* *} \mathrm{P}<0.01$ and ${ }^{* * *} \mathrm{P}<0.001$ vs. CTRL. A total of 100 cells were analysed in each experimental group. CTRL, control cells; SM, senescence medium; TM, tumour medium; B16, B16F10 cell line.

types and small cell carcinoma of the lung (37). The present study characterized the phenotype of DTX-induced senescent cells. DTX has already been described to induce cellular senescence in several tumour cell lines in a limited number of studies $(38,39)$. DNA damage following DTX treatment was previously described in MCF7 cells (40) and in p53-non-functional MDA-MB-231 cells (41). However, the effects of DTX in terms of senescence induction remain not fully described or understood. The presence of micronuclei along with $\gamma \mathrm{H} 2 \mathrm{AX}$ foci in DTX-treated cells in the present study indicates at the generation of DNA double-strand breaks prior to or during mitosis, resulting in the activation of persisting cell cycle checkpoints and the development of senescence in daughter cells. A previous study demonstrated the therapeutic effects of DTX on TC-1 cells in several experiments (42) and, notably, demonstrated that DTX induced senescence in the TC-1 cells (and TRAMP-C2 cells), which accelerated tumour growth when co-cultured with proliferating tumour cells (28). The present study provides further insight and, notably, demonstrates the capacity of SASP from DTX-induced cells to induce 'bystander' senescence. In two murine cell lines, DTX induced cellular stress and proliferation arrest, accompanied by the increased production of IL-6 and GRO $\alpha$, typical (although not exclusively) components of SASP. Concurrent with previously published results, the results of the present study demonstrate that DTX is capable of inducing stable senescence in different tumour cell lines with the capacity to induce genotoxic stress and senescence in neighbouring cells.

It has been previously demonstrated that IFN $\gamma$ or IFN $\gamma+\mathrm{TNF} \alpha$ induce cellular stress and proliferation arrest/senescence, or even apoptosis, in certain cell lineages (27). This is associated with the induction of the transforming growth factor- $\beta$ signalling pathway and subsequent induction of NADPH oxidase 4 protein and oxidative stress (17). The results of the present study indicated that the reason why the TC- 1 cell line did not undergo cell arrest was due to a lack of oxidative stress. Previously, it has been demonstrated that the cytostatic effects of IFN $\gamma$ on B16 cells (B16 cells expressing the ubiquitination-based cell cycle indicator) were associated with G1 arrest, mediated by the induction of p27 (43).

The present study evaluated the effects of IFN $\gamma+\mathrm{TNF} \alpha$ treatment on B16 cells. The data demonstrated a cytostatic effect, as opposed to the true senescence-inducing effect 
of IFN $\gamma+\mathrm{TNF} \alpha$ in B16 cells. Notably, unlike TC- 1 cells, $\mathrm{IFN} \gamma+\mathrm{TNF} \alpha$-treated $\mathrm{B} 16$ cells produced elevated amounts of GRO $\alpha$, a principle component of SASP that serves a role in senescence induction and maintenance in a paracrine manner (1). However, the treated B16 cells injected into mice resulted in tumour growth. Furthermore, the cells did not produce SASP capable of inducing 'bystander' senescence, suggesting that other components or higher concentrations of IL- 6 and GRO $\alpha$ are required. This indicates a lack of paracrine cytokine loop components contributing to senescence maintenance (44).

In conclusion, the results of the present study indicate that DTX induces senescence in TC- 1 and B16 cells. Furthermore, in $\mathrm{B} 16$ cells, IFN $\gamma+\mathrm{TNF} \alpha$ treatment induces a reversible proliferation arrest, as opposed to true senescence, despite the fact that this treatment induced certain senescence markers. TC -1 cells were indicated to be resistant to IFN $\gamma+\mathrm{TNF} \alpha$ treatment. These results suggest that each senescent inducer must therefore be studied in the context of a specific cell type.

\section{Acknowledgements}

The authors would like to thank Mrs Renáta Turečková (Institute of Molecular Genetics of the Czech Academy of Sciences, Czech Republic) for skilful technical assistance and Dr Šárka Takáčová (Institute of Molecular Genetics of the Czech Academy of Sciences, Czech Republic) for editorial assistance.

\section{Funding}

The present study was supported by the Czech Science Foundation (grant nos. 15-24769S and 15-03379S), the Academy of Sciences of the Czech Republic (grant no. RVO 68378050), the ministry of Education (grant no. LM2015040 to the Czech Centre for Phenogenomics), the Youth and Sports and European Regional Development Fund and Smartbrain (project DiaNa21).

\section{Availability of data and materials}

All data generated or analyzed during this study are included in this published article.

\section{Authors' contributions}

OS and RM performed the molecular studies, in vivo assays, statistical analysis and drafted the manuscript. JB performed fluorescence-activated cell sorting measuring and analysis. BM helped with the molecular studies and statistical analysis. MR and $\mathrm{ZH}$ designed the study and helped to draft the manuscript. All authors read and approved the final manuscript.

\section{Ethics approval and consent to participate}

All experiments were performed according to the EU Directive 2010/63/EU on the protection of animals used for scientific purposes. Experimental protocols were ethically approved by the Institutional Animal Care Committee of the Institute of Molecular Genetics (Prague, Czech Republic).

\section{Patient consent for publication}

Not applicable.

\section{Competing interests}

The authors declare that they have no competing interests.

\section{References}

1. Coppé JP, Desprez PY, Krtolica A and Campisi J: The senescence-associated secretory phenotype: The dark side of tumor suppression. Annu Rev Pathol 5: 99-118, 2010.

2. Coppé JP, Patil CK, Rodier F, Sun Y, Muñoz DP, Goldstein J Nelson PS, Desprez PY and Campisi J: Senescence-associated secretory phenotypes reveal cell-nonautonomous functions of oncogenic RAS and the p53 tumor suppressor. PLoS Biol 6: 2853-2868, 2008.

3. Benvenuti S, Cramer R, Bruce J, Waterfield MD and Jat PS: Identification of novel candidates for replicative senescence by functional proteomics. Oncogene 21: 4403-4413, 2002.

4. Bringold $\mathrm{F}$ and Serrano M: Tumor suppressors and oncogenes in cellular senescence. Exp Gerontol 35: 317-329, 2000.

5. Cristofalo VJ, Lorenzini A, Allen RG, Torres C and Tresini M: Replicative senescence: A critical review. Mech Ageing Dev 125: 827-848, 2004

6. Salama R, Sadaie M, Hoare M and Narita M: Cellular senescence and its effector programs. Genes Dev 28: 99-114, 2014.

7. Pluquet O, Pourtier A and Abbadie C: The unfolded protein response and cellular senescence. A review in the theme: Cellular mechanisms of endoplasmic reticulum stress signaling in health and disease. Am J Physiol Cell Physiol 308: C415-C425, 2015.

8. Kojima H, Inoue T, Kunimoto H and Nakajima K: IL-6-STAT3 signaling and premature senescence. JAK-STAT 2: e25763, 2013.

9. Hayflick L and Moorhead PS: The serial cultivation of human diploid cell strains. Exp Cell Res 25: 585-621, 1961.

10. d'Adda di Fagagna F, Reaper PM, Clay-Farrace L, Fiegler H, Carr P, Von Zglinicki T, Saretzki G, Carter NP and Jackson SP: A DNA damage checkpoint response in telomere-initiated senescence. Nature 426: 194-198, 2003.

11. Harley CB, Futcher AB and Greider CW: Telomeres shorten during ageing of human fibroblasts. Nature 345: 458-460, 1990.

12. Blazkova H, Krejcikova K, Moudry P, Frisan T, Hodny Z and Bartek J: Bacterial intoxication evokes cellular senescence with persistent DNA damage and cytokine signalling. J Cell Mol Med 14: 357-367, 2010.

13. Cairney CJ, Bilsland AE, Evans TR, Roffey J, Bennett DC, Narita M, Torrance CJ and Keith WN: Cancer cell senescence: A new frontier in drug development. Drug Discov Today 17: 269-276, 2012.

14. Kuilman T, Michaloglou C, Mooi WJ and Peeper DS: The essence of senescence. Genes Dev 24: 2463-2479, 2010.

15. Pascal T, Debacq-Chainiaux F, Chrétien A, Bastin C, Dabée AF, Bertholet V, Remacle J and Toussaint O: Comparison of replicative senescence and stress-induced premature senescence combining differential display and low-density DNA arrays. FEBS Lett 579: 3651-3659, 2005.

16. Davalos AR, Coppe JP, Campisi J and Desprez PY: Senescent cells as a source of inflammatory factors for tumor progression. Cancer Metastasis Rev 29: 273-283, 2010.

17. Hubackova S, Krejcikova K, Bartek J and Hodny Z: IL1- and TGF $\beta$-Nox4 signaling, oxidative stress and DNA damage response are shared features of replicative, oncogene-induced, and drug-induced paracrine 'bystander senescence'. Aging (Albany NY) 4: 932-951, 2012.

18. Calcinotto A and Alimonti A: Aging tumour cells to cure cancer: 'pro-senescence' therapy for cancer. Swiss Med Wkly 147: w14367, 2017.

19. Ortiz-Montero P, Londoño-Vallejo A and Vernot JP: Senescenceassociated IL-6 and IL- 8 cytokines induce a self- and cross-reinforced senescence/inflammatory milieu strengthening tumorigenic capabilities in the MCF-7 breast cancer cell line. Cell Commun Signal 15: 17, 2017.

20. Rodier F and Campisi J: Four faces of cellular senescence. J Cell Biol 192: 547-556, 2011. 
21. Nelson G, Wordsworth J, Wang C, Jurk D, Lawless C, MartinRuiz $\mathrm{C}$ and von Zglinicki T: A senescent cell bystander effect Senescence-induced senescence. Aging Cell 11: 345-349, 2012.

22. Hodny Z, Hubackova S and Bartek J: Cytokines shape chemotherapy-induced and 'bystander' senescence. Aging (Albany NY) 2: 375-376, 2010.

23. Kuilman T, Michaloglou C, Vredeveld LC, Douma S, van Doorn R, Desmet CJ, Aarden LA, Mooi WJ and Peeper DS: Oncogene-induced senescence relayed by an interleukin-dependent inflammatory network. Cell 133: 1019-1031, 2008

24. Ozturk M, Arslan-Ergul A, Bagislar S, Senturk S and Yuzugullu H: Senescence and immortality in hepatocellular carcinoma. Cancer Lett 286: 103-113, 2009.

25. Koturbash I, Rugo RE, Hendricks CA, Loree J, Thibault B, Kutanzi K, Pogribny I, Yanch JC, Engelward BP and Kovalchuk O: Irradiation induces DNA damage and modulates epigenetic effectors in distant bystander tissue in vivo Oncogene 25: 4267-4275, 2006.

26. Zhou H, Randers-Pehrson G, Waldren CA, Vannais D, Hall EJ and Hei TK: Induction of a bystander mutagenic effect of alpha particles in mammalian cells. Proc Natl Acad Sci USA 97: 2099-2104, 2000.

27. Braumüller H, Wieder T, Brenner E, Aßmann S, Hahn M, Alkhaled M, Schilbach K, Essmann F, Kneilling M, Griessinger C, et al: T-helper-1-cell cytokines drive cancer into senescence. Nature 494: 361-365, 2013.

28. Simova J, Sapega O, Imrichova T, Stepanek I, Kyjacova L, Mikyskova R, Indrova M, Bieblova J, Bubenik J, Bartek J, et al: Tumor growth accelerated by chemotherapy-induced senescent cells is suppressed by treatment with IL-12 producing cellular vaccines. Oncotarget 7: 54952-54964, 2016.

29. Lin KY, Guarnieri FG, Staveley-O'Carroll KF, Levitsky HI August JT, Pardoll DM and Wu TC: Treatment of established tumors with a novel vaccine that enhances major histocompatibility class II presentation of tumor antigen. Cancer Res 56 : 21-26, 1996.

30. Overwijk WW and Restifo NP: B16 as a mouse model for human melanoma. Curr Protoc Immunol Chapter 20: Unit 20.1, 2001.

31. Livak KJ and Schmittgen TD: Analysis of relative gene expression data using real-time quantitative PCR and the 2(-Delta Delta C(T)) method. Methods 25: 402-408, 2001.

32. Ramirez JM, Bai Q, Péquignot M, Becker F, Kassambara A, Bouin A, Kalatzis V, Dijon-Grinand M and De Vos J: Side scatter intensity is highly heterogeneous in undifferentiated pluripotent stem cells and predicts clonogenic self-renewal. Stem Cells Dev 22: 1851-1860, 2013 .

33. Zhang YH, Lin JX and Vilcek J: Interleukin-6 induction by tumor necrosis factor and interleukin-1 in human fibroblasts involves activation of a nuclear factor binding to a kappa B-like sequence. Mol Cell Biol 10: 3818-3823, 1990.
34. Hubackova S, Kucerova A, Michlits G, Kyjacova L, Reinis M, Korolov O, Bartek J and Hodny Z: IFN $\gamma$ induces oxidative stress, DNA damage and tumor cell senescence via TGF $\beta / S M A D$ signaling-dependent induction of Nox 4 and suppression of ANT2. Oncogene 35: 1236-1249, 2016.

35. Mukherjee S, Debata PR, Hussaini R, Chatterjee K, Baidoo JN Sampat S, Szerszen A, Navarra JP, Fata J, Severinova E, et al: Unique synergistic formulation of curcumin, epicatechin gallate and resveratrol, tricurin, suppresses HPV E6, eliminates $\mathrm{HPV}^{+}$ cancer cells, and inhibits tumor progression. Oncotarget 8: 60904-60916, 2017.

36. Novakova Z, Hubackova S, Kosar M, Janderova-Rossmeislova L, Dobrovolna J, Vasicova P, Vancurova M, Horejsi Z, Hozak P, Bartek J, et al: Cytokine expression and signaling in druginduced cellular senescence. Oncogene 29: 273-284, 2010.

37. Ringel I and Horwitz SB: Studies with RP 56976 (taxotere): A semisynthetic analogue of taxol. J Natl Cancer Inst 83: 288-291, 1991.

38. Schwarze SR, Fu VX, Desotelle JA, Kenowski ML and Jarrard DF: The identification of senescence-specific genes during the induction of senescence in prostate cancer cells. Neoplasia 7: 816-823, 2005.

39. Di Mitri D, Toso A, Chen JJ, Sarti M, Pinton S, Jost TR, D'Antuono R, Montani E, Garcia-Escudero R, Guccini I, et al: Tumour-infiltrating Gr-1+ myeloid cells antagonize senescence in cancer. Nature 515: 134-137, 2014

40. Hernández-Vargas H, Palacios J and Moreno-Bueno G: Molecular profiling of docetaxel cytotoxicity in breast cancer cells: Uncoupling of aberrant mitosis and apoptosis. Oncogene 26: 2902-2913, 2007.

41. Hernández-Vargas H, Palacios J and Moreno-Bueno G: Telling cells how to die: Docetaxel therapy in cancer cell lines. Cell Cycle 6: 780-783, 2007.

42. Mikyšková R, Štěpánek I, Indrová M, Bieblová J, Šímová J, Truxová I, Moserová I, Fučíková J, Bartůňková J, Špíšek R, et al: Dendritic cells pulsed with tumor cells killed by high hydrostatic pressure induce strong immune responses and display therapeutic effects both in murine TC-1 and TRAMP-C2 tumors when combined with docetaxel chemotherapy. Int J Oncol 48: 953-964, 2016

43. Kakimi K, Matsushita H, Hosoi A, Miyai M and Ohara O: CTLs regulate tumor growth via cytostatic effects rather than cytotoxicity: A few T cells can influence the growth of many times more tumor cells. OncoImmunology 4: e970464, 2014

44. Bartek J, Hodny Z and Lukas J: Cytokine loops driving senescence. Nat Cell Biol 10: 887-889, 2008.

This work is licensed under a Creative Commons Attribution-NonCommercial-NoDerivatives 4.0 International (CC BY-NC-ND 4.0) License. 